the exhibit is, indeed, almost a perfect replica of the home of the famous Revolutionary War hero. Then, too, there is the Washington room whose general motif is taken from the west parlor at Mount Vernon.

The Foyer Hall, the heart of the building, is a reproduction of the foyer in Independence Hall which adjoins the chamber in which the Declaration of Independence was signed. Relics of the days when Spain ruled the American continent displayed in the Spanish Exploration room help the visitor to visualize America in the period of the Spanish conquest. To describe all of the period rooms is beyond the scope of this short review, but by suggesting a few titles such as the French alcove, the New Republic room, the Civil War room, and the World War Memorial room, it is possible to show that the Museum does give an excellent pictorial account of America's development.

The Chicago Historical Society never has received and does not receive tax support, but is operated through gifts, interest on endowment, memberships, and door fees. The Society is administered by a board of twenty-four trustees, a president, two vice presidents, a secretary, and a treasurer. The active administration of the building is in the hands of the director, which office is now filled by Mr. L. Hubbard Shattuck.

\title{
Industrial Pictures and their Relation to Business History
}

For several years the Society has been active in securing action photographs of industrial processes for deposit in the Baker Library, and during the past year the organization has carried on an intense campaign to enlarge this collection. Because of these efforts, the number of pictures has been increased to a point where there are now over two thousand items.

Manufacturers in practically all fields of American business have contributed to the collection. Some of the companies have donated pictures covering every mechanical operation in their respective plants; while most of the contributors have given photographs that deal with the more important processes in their factories. All of these pictures show machines in actual operation. 
The photographs are used principally in the classes of the Harvard Business School as a supplement to the regular case-book instruction. These action pictures are especially valuable in the industrial management classes because they portray so clearly such practical industrial problems as the relationship between the laborer and the machine. Displays of industrial photographs may also be found at almost all times in the corridors, class-rooms, or study-rooms of the Baker Library.

\section{Boston Custom-House}

THAT the Boston collector of custom in the year 1843 was a proverbial "Jack of all trades" is revealed in a letter-book of the Boston Custom-House in the files of the Baker Library. Detector of criminals and smugglers, benefactor of sailors in distress, counsel for importing merchants, and adviser for foreign consuls - these were all tasks within the range of duties of this custom-house.

Questions such as "Is a British ship allowed under the laws of this country to clear and trade from port to port in the United States?", "What is the duty on brown sugar?", and "How much wool was imported through the Boston Harbor in 1842 ?" are typical of the routine inquiries which the Boston custom collector had to answer. At times the official found it expedient to set aside certain custom regulations. For instance, when a student of natural history requested that the usual examination be waived on four boxes of goods he was importing, because the contents of the boxes (oxhorns, buffalo bones, and rare insects) would be ruined by such an inspection, the request was granted.

For the layman it doesn't matter much whether an alewife and a herring are of the same or distinctly different species of fish, but for purposes of custom-house administration, the distinction was a thing of great moment. After a careful investigation, it was decided to the satisfaction of the custom officials that the alewife and herring were two distinct species; the alewife has a deeply notched upper jaw and four or five stripes running from head to tail, while the herring is not so marked.

Smuggling is a major problem confronting any customs agent, but from the letters it appears that the Boston Custom-House had an abnormal amount of such trouble. A great deal of this difficulty 